\title{
KONZERVEK HŐKEZELÉSÉNEK KÖLTSÉGCSÖKKENTÉSE GYÁRTÁSPROGRAMOZÁSSAL
}

\author{
Fabulya Zoltán
}

\begin{abstract}
SUMMARY
Examination of the load-efficiency graph of the boiler showed that gas fee which determines the direct expenses significantly can be reduced by $6 \%$ if the load is balanced. It is typical to the present practice that when different products of different load are made at the same time, it is not taken into consideration when the shifts are planned. Then, for example, instead of the average load of $50 \%$ per shift it is typical that even the average load of $30 \%$ and of $70 \%$ can be observed in the consecutive shifts. However, even within one shift great deviations can be experienced because the production is not scheduled. It can be seen from the results that the increase of the unbalanced feature of the load results in the growth of the loss. With smaller average loads, balancing the load is of a bigger importance since the relative loss can be even $6 \%$ then. Besides the load of $50 \%$, which can be regarded as the annual average, almost the loss of $5 \%$ was experienced in the worst case.
\end{abstract}

\section{BEVEZETÉS}

A konzervek hőkezelése, különösen húskonzervek esetén nagy energiaigényü folyamat, mivel sterilezéssel, $120^{\circ} \mathrm{C}$ körüli, hosszú időtartamú hőhatással jár. A termékek minősége és a költséghatékony termelés érdekében mérnöki számításokat, modellezést, számítógépes szimulációt érdemes bevonni a témakör kutatásába. Fő célom a konzervgyártásban autokláv csoportot alkalmazó technológiák esetében egy szimulációra támaszkodó programrendszer készítése, mellyel csökkenthető a hőkezelés közvetlen költsége és megelőzhető a termék minőségi károsodása.

A szakirodalmakban a 70-es években az általános hőveszteség kérdésével foglalkoztak (Rao et al. 1976, Rao et al. 1978, Singh 1978). A 80-as években a hőhasznosítás és höfelvételi arányok témakörében jelentek meg közlemények (Sielaff et al. 1982; Bhowmik et al. 1985, Singh 1986). Az újabb kutatások a höbehatolás intenzitásának növelésére irányulnak, amit viszkózus élelmiszereknél a konzervek hőkezelés közbeni, megfelelő sebességü forgatásával lehet elérni erre alkalmas autoklávval (Yang-Rao 1998, Akterian 1995, Alonso et al. 1997, MengRamaswamy 2005, 2007a, 2007b). Szimulációs optimalizáló ütemezést is alkalmaztak azzal a céllal, hogy különbözö termékeket együtt hökezeljenek azonos alkalmazandó sterilképlet esetén, s így rövidebb várakozási időt alkalmazva a kezelés megkezdéséig (Simpson 2004, Simpson-Abakarov 2009).

A kutatások viszont eddig nem foglalkoztak a termék minőségére és a hőkezelés közvetlen költségére is pozitívan ható termelés-szervezési kérdésekkel, autokláv csoport összehangolt müködtetésével, mellyel megfelelö ütemezettséggel indítva a hőkezelési folyamatokat egyenletes erőforrás-felhasználás (gőz, víz) biztosítja a kiegyensúlyozott termelést.

A vállalatok valamilyen rendszerességgel gyártási tervet készítenek a következő időszakra. A kutatási terepet biztosító vállalatnál heti rendszerességgel a következő 
hét gyártási tervét állítják össze, melynek legfontosabb eleme, hogy az egyes müszakokban mely termékeik gyártására kerüljön sor. Több gyártósorral rendelkeznek, és termékfüggő, hogy a termék melyik soron gyártható. A terv és az abból adódó folyamatok adatai a jelenlegi gyakorlatban számítógépes ellenőrzés nélküliek, emiatt emberi figyelmetlenség folytán könnyen adódhat probléma.

\section{A PROGRAM FUTTATÁSI TAPASZTALATAI}

Korábbi kutatásomban általánosságban mutattam be a kazánterhelés kiegyensúlyozásának költségcsökkentő szerepét (Fabulya 2011), valamint a program fejlesztését (Fabulya-Hampel 2010). Az elkészült program birtokában már számszerü eredményekkel mutathatom be a használat során adódott költségcsökkenést.

\subsection{MÜSZAKOK KIEGYENLÍTETT KAZÁNTERHELÉSE}

A program szimulátorával akár ötperces bontásban autoklávonként megkaphatjuk a hőkezelések okozta gőzfelhasználás adatsorát egy teljes hétre. Ezekből az adatokból részösszegként kaphatjuk meg az egyes műszakok gőzigényét, s így a kazán terhelését százalékban. Korábbi eredményünk alapján a terheléshez tartozó hatásfok adódik. Az 1. táblázatban foglaltam össze egy hét esetén az eredeti és a terhelés müszakok közötti kiegyenlítése utáni állapotának szimulációval kapott adatait.

\section{1. táblázat: Mủszakok kazánterhelésének kiegyenlítése}

\begin{tabular}{|c|c|r|r|r|r|}
\hline \multirow{2}{*}{ Nap } & \multirow{2}{*}{ Múszak } & \multicolumn{2}{|c|}{ Kiegyenlítés nélkül } & \multicolumn{2}{|c|}{ Kiegyenlítve } \\
\cline { 3 - 6 } & & Kazánterhelés & hatásfok & Kazánterhelés & hatásfok \\
\hline 2009.06 .15 & 1 & $45 \%$ & $76 \%$ & $45 \%$ & $76 \%$ \\
2009.06 .15 & 2 & $37 \%$ & $73 \%$ & $47 \%$ & $77 \%$ \\
2009.06 .15 & 3 & $49 \%$ & $78 \%$ & $49 \%$ & $78 \%$ \\
2009.06 .16 & 1 & $33 \%$ & $71 \%$ & $53 \%$ & $79 \%$ \\
2009.06 .16 & 2 & $22 \%$ & $65 \%$ & $47 \%$ & $77 \%$ \\
2009.06 .16 & 3 & $41 \%$ & $75 \%$ & $51 \%$ & $78 \%$ \\
2009.06 .17 & 1 & $27 \%$ & $68 \%$ & $47 \%$ & $77 \%$ \\
2009.06 .17 & 2 & $20 \%$ & $63 \%$ & $60 \%$ & $81 \%$ \\
2009.06 .17 & 3 & $38 \%$ & $73 \%$ & $53 \%$ & $79 \%$ \\
2009.06 .18 & 1 & $82 \%$ & $87 \%$ & $52 \%$ & $79 \%$ \\
2009.06 .18 & 2 & $46 \%$ & $77 \%$ & $46 \%$ & $77 \%$ \\
2009.06 .18 & 3 & $75 \%$ & $86 \%$ & $55 \%$ & $80 \%$ \\
2009.06 .19 & 1 & $92 \%$ & $89 \%$ & $52 \%$ & $79 \%$ \\
2009.06 .19 & 2 & $46 \%$ & $77 \%$ & $46 \%$ & $77 \%$ \\
2009.06 .19 & 3 & $75 \%$ & $86 \%$ & $55 \%$ & $80 \%$ \\
\hline \multicolumn{2}{|c|}{ Átlagok } & $49 \%$ & $75,8 \%$ & $49 \%$ & $78,2 \%$ \\
\hline
\end{tabular}

Forrás: A szerzỏ saját szerkesztése 
A táblázat utolsó sorában az átlagok adatait kell a továbbiákban felhasználni. A kazánterhelésre adódott $49 \%$ természetesen a kiegyenlítés hatására nem változott, hiszen ugyanazokat a termékeket változatlan mennyiségben kell hökezelni csak a müszakok közötti más elosztásban. Viszont az egyenletesebb kazánterhelés jobb hatásfokot biztosít.

A hét során a kazán fütésére felhasznált gáz mennyiségéből (G), fütőértékéből (F) és a hatásfokból ( $\eta$ ) kiszámítható az előállított gőz hőenergiája (E), ami a kazán terhelését jelzi:

$$
\mathrm{E}=\mathrm{G} \cdot \mathrm{F} \cdot \eta
$$

Ebből adódik, hogy a hőkezelések elvégzéséhez szükséges energia, mekkora mennyiségü fütőgázt igényel:

$$
\mathrm{G}=\frac{\mathrm{E}}{\mathrm{F} \cdot \eta}
$$

Változatlan hőigény (E) mellett a rosszabb hatásfok nagyobb gázmennyiséget jelent. A magasabb gázigény százalékban kifejezhető:

$$
\frac{G_{1}}{G_{2}}=\frac{\frac{E}{F \cdot \eta_{1}}}{\frac{E}{F \cdot \eta_{2}}}=\frac{\eta_{2}}{\eta_{1}}=\frac{78,2 \%}{75,8 \%}=1,032
$$

Ahol:

E - a gőz hőenergiája (MJ)

$\mathrm{F}$ - a gáz fütőértéke $\left(\mathrm{MJ} / \mathrm{m}^{3}\right)$

$\mathrm{G}_{1}$ - a gáz mennyisége a kazánterhelés kiegyenlítése nélkül $\left(\mathrm{m}^{3}\right)$ '

$\eta_{1}$ - a kazán hatásfoka a kazánterhelés kiegyenlítése nélkül

$\mathrm{G}_{2}$ - a gáz mennyisége kiegyenlített kazánterhelésnél $\left(\mathrm{m}^{3}\right)$

$\eta_{2}$ - a kazán hatásfoka kiegyenlített kazánterhelésnél

Tehát 3,2\%-kal több gázra van szükség a kazán terhelésének müszakok közötti kiegyenlítése nélkül. Más hetekben is elvégezve a szimulációt és a terhelés kiegyenlítését 3\% és 5\% közötti eredmények adódtak. Ez évenként 3-5 millió Ft-ot jelent 100 millió Ft éves gázdíjat alapnak tekintve.

\subsection{KÖLTSÉGCSÖKKENTÉS A HŐKEZELÉSEK ÜTEMEZÉSÉVEL}

Az előző pontban bemutatottakhoz hasonlóan itt is a kazán terhelésének időben kiegyensúlyozása történik, de most egy müszakon belül ütemezéssel, a hőkezelések megkezdésének várakoztatásával összehangolva a folyamatokat. A 2. táblázatban egy műszak kazánterhelésének szimulációval kapott ötperces felbontású idősor adatai láthatók ütemezés nélkül és ütemezéssel. 


\section{2. táblázat: Ütemezés hatása a kazánterhelésre}

\begin{tabular}{|c|c|c|c|c|c|c|}
\hline \multirow{2}{*}{ Nap } & \multirow{2}{*}{ Müszak } & \multirow{2}{*}{ Idő } & \multicolumn{2}{|c|}{ Ütemezés nélkül } & \multicolumn{2}{|c|}{ Ütemezve } \\
\hline & & & Kazánterhelés & hatásfok & Kazánterhelés & hatásfok \\
\hline 2009.06.15 & 1 & $6: 00$ & $45 \%$ & $76 \%$ & $38 \%$ & $73 \%$ \\
\hline 2009.06.15 & 1 & $6: 05$ & $43 \%$ & $75 \%$ & $37 \%$ & $73 \%$ \\
\hline 2009.06.15 & 1 & $6: 10$ & $42 \%$ & $75 \%$ & $61 \%$ & $82 \%$ \\
\hline 2009.06 .15 & 1 & $6: 15$ & $75 \%$ & $85 \%$ & $59 \%$ & $81 \%$ \\
\hline 2009.06 .15 & 1 & $6: 20$ & $74 \%$ & $85 \%$ & $58 \%$ & $81 \%$ \\
\hline 2009.06.15 & 1 & $6: 25$ & $74 \%$ & $85 \%$ & $57 \%$ & $80 \%$ \\
\hline 2009.06.15 & 1 & $6: 30$ & $73 \%$ & $85 \%$ & $50 \%$ & $78 \%$ \\
\hline 2009.06 .15 & 1 & $6: 35$ & $65 \%$ & $83 \%$ & $50 \%$ & $78 \%$ \\
\hline 2009.06 .15 & 1 & $6: 40$ & $60 \%$ & $81 \%$ & $49 \%$ & $78 \%$ \\
\hline 2009.06 .15 & 1 & $13: 45$ & $17 \%$ & $61 \%$ & $41 \%$ & $75 \%$ \\
\hline 2009.06 .15 & 1 & $13: 50$ & $16 \%$ & $60 \%$ & $40 \%$ & $74 \%$ \\
\hline 2009.06 .15 & 1 & $13: 55$ & $16 \%$ & $60 \%$ & $40 \%$ & $74 \%$ \\
\hline \multicolumn{3}{|c|}{ Átlagok } & $45 \%$ & $74,9 \%$ & $45 \%$ & $78,4 \%$ \\
\hline
\end{tabular}

Forrás: A szerző saját szerkesztése

A 2. táblázatot tanulmányozva kisebb félreértésre adhat okot, hogy a táblázat felső részén magasabb hatásfokok szerepelnek az ütemezés nélküli esetben. Ez azzal magyarázható, hogy magasabb terhelésnél ugyan jobb a hatásfok, de kisebb mértékben, mint az alacsonyabb terheléskor megjelenő hatásfok csökkenés. Az ütemezés a terhelés kiegyenlítésére irányul. Így kevésbé lép fel a magasabb terhelésekhez tartozó jobb hatásfok, de az alacsonyabb terhelések melletti sokkal rosszabb hatásfok is. Az utolsó sorban látható, hogy az ütemezés hatására jobb átlagos hatásfokkal állítható elő a gőz. A (4) összefüggéssel határozható meg az ütemezetlen állapot magasabb gázigénye százalékban:

$$
\frac{\mathrm{G}_{1}}{\mathrm{G}_{2}}=\frac{\eta_{2}}{\eta_{1}}=\frac{78,4 \%}{74,9 \%}=1,047
$$

Ahol:

$\mathrm{G}_{1}$ - a gáz mennyisége ütemezés nélkül $\left(\mathrm{m}^{3}\right)$

$\eta_{1}$ - a kazán hatásfoka ütemezés nélkül

$\mathrm{G}_{2}$ - a gáz mennyisége ütemezett esetben $\left(\mathrm{m}^{3}\right)$

$\eta_{2}$ - a kazán hatásfoka ütemezett esetben

Tehát 4,7\%-kal több gázra van szükség a müszak során ütemezés nélkül. Több müszakban is elvégezve a szimulációt és az ütemezést most is $3 \%$ és $5 \%$ közötti eredmények adódtak, ami szintén 100 millió Ft bázisértéket tekintve 3-5 millió Ft megtakarítást jelent évente. 


\section{3. ÖSSZEFOGLALÁS}

A szimulációs optimalizáláshoz, gyártásprogramozáshoz kialakított szoftverhez az Excel alkalmazható felhasználóbarát módon az adatok tárolására, feldolgozására, grafikus megjelenítésére, programozási feladatok ellátására, míg az Access ürlapos adatbevitelre, lekérdezések és jelentések kialakítására. A kialakított számítógépes rendszer egyszerüen kezelhető lehetőséget biztosít az adatbevitelre, módosításra, gyártósori termékütközés ellenörzésére, hőkezelési hosszú várakozó sorok elkerülésére autokláv kapacitás ellenörzésével, müszakok gázfelhasználásának kiegyensúlyozására, valamint gázfelhasználási csúcsok elkerülésére ütemezéssel. Mindezekkel biztosítva a jobb minőségü termékek előállítását alacsonyabb közvetlen költségek mellett.

\section{IRODALOMJEGYZÉK}

Akterian, S. G. (1995): Numerical simulation of unsteady heat transfer in canned mushrooms in brine during sterilization processes. Journal of Food Engineering 25(1), pp. 45-53, ISSN 02608774, DOI: $10.1016 / 0260-8774(95) 93015-\mathrm{N}$.

Alonso, A. A. - Banga, J. R. - Perez-Martin, R. (1997): A complete dynamic model for the thermal processing of bioproducts in batch units and its application to controller design. Chemical Engineering Science 52(8), pp. 1307-1322, ISSN 0009-2509, DOI: 10.1016/S00092509(96)00484-8.

Bhowmik, S. R. - Vichnevetsky, R. - Hayakawa, K. I. (1985): Mathematical model to estimate steam consumption in vertical still retort for thermal processing of canned foods. Lebensmittelwissenschaft und Technologie 18(1), pp. 15-23.

Fabulya Z. - Hampel Gy. (2010): Adatbázis alkalmazási lehetőségei autoklávos hőkezelésnél. Jelenkori társadalmi és gazdasági folyamatok 5(1-2), Szegedi Tudományegyetem Mérnöki Kar, Szeged, pp. 239-243., ISSN 1788-7593

Fabulya Z. (2011): Kazán jelleggörbe elemzése hőkezelési folyamat optimalizálásához. Jelenkori társadalmi és gazdasági folyamatok 6(1-2), Szegedi Tudományegyetem Mérnöki Kar, Szeged, pp. 19-23., ISSN 1788-7593

Meng, Y. - Ramaswamy, H. S. (2005): Heat Transfer Coefficients Associated with Canned Particulate/Non-Newtonian Fluid (CMC) System During End-Over-End Rotation. Food and Bioproducts Processing 83(3), pp. 229-237, ISSN 0960-3085, DOI: 10.1205/fbp.04076.

Meng Y. - Ramaswamy, H. S. (2007a): Effect of System Variables on Heat Transfer to Canned Particulate Non-Newtonian Fluids During End-Over-End Rotation. Food and Bioproducts Processing 85(1), pp. 34-41, ISSN 0960-3085, DOI: 10.1205/fbp.06007.

Meng, Y. - Ramaswamy, H. S. (2007b): System variables affecting heat transfer in a canned particle in Newtonian fluid system during end-over-end rotation. LWT - Food Science and Technology 40(7), pp. 1240-1245, ISSN 0023-6438, DOI: 10.1016/j.lwt.2006.08.010.

Rao, M. A. - Kenny, J. F. - Katz, J. - Downing, D.L. (1976): Computer estimation of heat losses in food processing plants. Food Technology 30(3), pp. 36-39., 42.

Rao, M. A. - Katz,J. - Goel, V.K. (1978): Economic evaluation of measures to conserve energy in food processing plants. Food Technology 32(4), pp. 34-39.

Sielaff, H. - Andrae, W. - Oelker, P. (1982): Herstellung von Fleischkonserven und industrielle Speisenproduktion. VEB Fachbuchverlag, Leipzig, pp. 230-239.

Simpson, R. (2004): Generation of isolethal processes and implementation of simultaneous sterilisation utilising the revisited general method. Journal of Food Engineering 67(1), pp. 7179, ISSN 0260-8774, DOI: 10.1016/j.jfoodeng.2004.05.061. 
Simpson, R. - Abakarov, A. (2009): Optimal scheduling of canned food plants including simultaneous sterilization. Journal of Food Engineering 90(1), pp. 53-59, ISSN 0260-8774, DOI: 10.1016/j.jfoodeng.2008.06.009.

Singh, R. P. (1978): Energy accounting in food process operations. Food Technology 32(4), pp. 40-43.

Singh, R. P. (ed.) (1986): Energy in Agriculture Volume I. Energy in Food Processing. Elsevier Amsterdam-Oxford-New York-Tokio, pp 163-170.

Yang, W. H. - Rao, M. A. (1998): Numerical study of parameters affecting broken heating curve. Journal of Food Engineering 37(1), pp. 43-61, ISSN 0260-8774, DOI: 10.1016/S02608774(98)00070-3. 